\title{
Brazilian sandy beaches: characteristics, ecosystem services, impacts, knowledge and priorities
}

\author{
Antonia Cecília Zacagnini Amaral ${ }^{1, *}$, Guilherme Nascimento Corte ${ }^{I}$, José Souto Rosa Filho ${ }^{2}$, \\ Marcia Regina Denadai ${ }^{3}$, Leonir André Colling ${ }^{4}$, Carlos Borzone ${ }^{5}$, Valéria Veloso ${ }^{12 \dagger}$, Elianne \\ Pessoa Omena ${ }^{6}$, Ilana Rosental Zalmon ${ }^{7}$, Cristina de Almeida Rocha-Barreira ${ }^{8}$, Jose Roberto \\ Botelho de Souza ${ }^{9}$, Leonardo Cruz da Rosa ${ }^{10}$, Tito Cesar Marques de Almeida ${ }^{11}$
}

\author{
${ }^{1}$ Departamento Biologia Animal (Zoologia), Instituto Biologia, Universidade Estadual de Campinas. \\ (Rua Monteiro Lobato 255, Cidade Universitária, CEP: 13083-862, Campinas, SP) \\ ${ }^{2}$ Laboratório de Bentos, Departamento de Oceanografia, Universidade Federal de Pernambuco. \\ (Av. Prof. Moraes Rêgo s/n, Cidade Universitária, CEP: 50670-901, Recife, PE) \\ ${ }^{3}$ Instituto Oceanográfico, Universidade de São Paulo. \\ (Praça do Oceanográfico 191, Cidade Universitária, CEP: 05508-120, São Paulo, SP) \\ ${ }^{4}$ Laboratório de Ecologia de Invertebrados Bentônicos, Instituto de Oceanografia/FURG. \\ (Av. Itália Km. 08, CxP. 474, CEP: 96203-000, Rio Grande, RS) \\ ${ }^{5}$ Centro de Estudos do Mar, Universidade Federal do Paraná. \\ (Av. Beira Mar s/n, Pontal do Sul, CEP: 83255-000, Pontal do Paraná, PR) \\ ${ }^{6}$ Fapese/CENPES/PETROBRAS. \\ (Av. Horácio de Macedo 950, Ilha do Fundão, CEP: 21941-915, Rio de Janeiro, RJ) \\ ${ }^{7}$ Laboratório de Ciências Ambientais, Universidade Estadual do Norte Fluminense Darcy Ribeiro. \\ (Av. Alberto Lamego 2000, Pq California, CEP: 22013-602, Campos dos Goytacazes, RJ) \\ ${ }^{8}$ Instituto de Ciências do Mar, Universidade Federal do Ceará. \\ (Av. Abolição 3207, Bairro Meireles, CEP: 60165-081, Fortaleza, CE) \\ ${ }_{9}^{9}$ Departamento de Zoologia, Centro de Ciências Biológicas, Universidade Federal de Pernambuco \\ (Av. Prof. Moraes Rego 1235, Cidade Universitária, CEP: 50670-901, Recife, PE) \\ ${ }^{10}$ Laboratório de Ecologia Bentônica, Departamento de Engenharia de Pesca e Aquicultura (DEPAq), Centro de Ciências Agrárias Aplicadas \\ (CCAA), Universidade Federal de Sergipe. \\ (Cidade Universitária Prof. José Aloísio de Campos, Rua Mal. Rondon s/n, Jardim Rosa Elze, CEP: 49100-000, São Cristóvão, SE) \\ ${ }^{11}$ Laboratório de Ecologia de Comunidades, Centro de Ciências da Terra e do Mar, Universidade do Vale do Itajaí. \\ (UNIVALI, Rua Uruguai 458, bloco 20, sala 144, Centro, CEP:88302-130, Itajaí, SC) \\ ${ }^{12}$ Instituto de Biociências - CCBS - UNIRIO. \\ (Av. Pasteur, 458 - Urca - RJ Cep: 22.290-240) \\ ${ }^{\dagger}$ In Memorian. \\ *Corresponding author: ceamaral@unicamp.br
}

\begin{abstract}
Sandy beaches constitute a key ecosystem and provide socioeconomic goods and services, thereby playing an important role in the maintenance of human populations and in biodiversity conservation. Despite the ecological and social importance of these ecosytems, Brazilian sandy beaches are significantly impacted by human interference, chemical and organic pollution and tourism, as well as global climate change. These factors drive the need to better understand the environmental change and its consequences for biota. To promote the implementation of integrated studies to detect the effects of regional and global environmental change on beaches and on other benthic habitats of the Brazilian coast, Brazilian marine researchers have established The Coastal Benthic Habitats Monitoring Network (ReBentos). In order to provide input for sample planning by ReBentos, we have conducted an intensive review of the studies conducted on Brazilian beaches and summarized the current knowledge about this environment. In this paper, we present the results of this review and describe the physical, biological and socioeconomics features of Brazilian beaches. We have used these results, our personal experience and worldwide literature to identify research projects that should be prioritized in the assessment of regional and global change on Brazilian sandy beaches. We trust that this paper will provide insights for future studies and represent a significant step towards the conservation of Brazilian beaches and their biodiversity.
\end{abstract}

Descriptors: Sandy beaches, Brazil, Macrofauna, Conservation, Coastal ecosystem.

\section{RESUMO}

As praias brasileiras fornecem bens e serviços ecossistêmicos fundamentais, desempenhando papel importante para a manutenção de populações humanas e para a conservação da biodiversidade. Entretanto, apesar da sua importância ecológica e social, essas praias são amplamente impactadas por alterações humanas, turismo, poluição química e orgânica e mudanças climáticas globais. Esses fatores tornam urgente a melhor percepção e compreensão das mudanças ambientais nas praias brasileiras, assim como de suas consequências na biota. Com o objetivo de promover estudos integrados que possam detectar variações nas características das praias e de outros habitats bentônicos do litoral do Brasil, foi estabelecida a Rede de Monitoramento de Habitats Bentônicos Costeiros (ReBentos). Para fornecer subsídios para o planejamento amostral da ReBentos, realizamos um intenso levantamento sobre os estudos conduzidos nas praias brasileiras e sintetizamos o atual conhecimento relativo a esse ambiente. Os resultados do levantamento são apresentados no presente trabalho e demonstram as principais características físicas, biológicas e socioeconômicas dessas praias. A partir das informações, assim como de nossa experiência e de pesquisas realizadas em diversos países, apontamos estudos e medidas que devem ser considerados prioritários para a avaliação dos efeitos das mudanças regionais e globais sobre as praias brasileiras. Esperamos que esse trabalho possa fornecer subsídios para futuros estudos e que constitua um importante passo em direção à conservação das praias do Brasil e de sua biodiversidade.

Descritores: Praias areianosas, Brasil, Macrofauna, Conservação, Ecossistemas costeiros. 


\section{INTRODUCTION}

Sandy beaches are the dominant coastal environment in most tropical and temperate regions (MCLACHLAN; BROWN, 2006). They are one of the marine environments most accessible to humans and are, consequently, very popular places for recreation. Due to these characteristics, beaches are the coastal environment most used by human populations and they sustain the economy of many cities around the world (KLEIN et al., 2004).

Although sandy beaches are primarily valued for their economic and recreational features (SCHLACHER et al., 2007), they are home to a diverse biota and provide basic goods and ecosystem services for environmental balance (DEFEO et al., 2009). The biological communities of sandy beaches are dominated by small organisms and structured mainly by the physicochemical characteristics of the environment, such as wave energy, tidal regime, slope, grain size, salinity, and dissolved oxygen (MCLACHLAN; BROWN, 2006). Consequently, the biota varies from beach to beach, and environmental, natural, or anthropogenic changes can have significant effects on the structure and functioning of a beach's biological communities.

The Brazilian coast extends for approximately 10,800 $\mathrm{km}$ - from Cape Orange $\left(4^{\circ} \mathrm{N}\right)$ to Chui $\left(34^{\circ} \mathrm{S}\right)$ - and has one of the largest collections of sandy beaches in the world. Contrary to their great geographical extent, knowledge about Brazilian beaches is reduced, and the information available on their biodiversity is insufficient to ensure their preservation. In addition to this limited knowledge, Brazilian economic development has historically consisted of poorly planned exploitation of natural resources, which has subjected Brazilian beaches to several types of human impacts that carry a high risk of biodiversity loss (AMARAL; JABLONSKY, 2005; SCHLACHER et al., 2008; SCHERER, 2013). Added to this are the effects of global climate change, thus, understanding Brazilian sandy beach ecosystems and predicting their response to possible environmental change has become increasingly critical and urgent.

To promote the implementation of integrated studies to detect the effects of regional and global environmental change on beaches and on other benthic habitats of the Brazilian coast, Brazilian marine researchers have established The Coastal Benthic Habitats Monitoring Network (ReBentos) (www.rebentos.org). One of the main objectives of ReBentos is the long-term monitoring of benthic biodiversity on the Brazilian coast, an approach that will generate a series of data that can be used to better understand environmental changes and their effects on the biota, as well as in the adoption of effective management and conservation strategies.

In order to summarize current knowledge on Brazilian beaches and to provide input for the future sampling design for research and monitoring by ReBentos, we conducted an intensive review of the studies performed in this environment. The results of this survey revealed that knowledge about Brazilian beaches is scant and much effort is needed to better understand and preserve this ecosystem. Here, we have combined these results, our personal experience and worldwide literature, to (1) physically characterize Brazilian beaches, (2) discuss their ecosystem goods and services, and (3) the main impacts and threats to these beaches, (4) determine the current body of knowledge on the biota of beach ecosystems and the knowledge gaps, (5) evaluate the applicability of this knowledge in identifying and predicting the effects of climate change, and (6) highlight the priorities for future studies for the conservation of Brazilian beaches and their biodiversity.

\section{MATERIAL AND METHODS}

To evaluate research on Brazilian sandy beaches, we searched for the following combination of keywords in the ISI Web of Science ${ }^{\circledR}$, SCOPUS, and Google Scholar databases $($ timespan $=$ all years; field $=$ topic $)$ : Brazil $*$ AND (beach* OR shore*) AND (benth* OR macrofauna). Only papers published in scientific journals and whose purpose was related to the ecology of benthic macrofauna of sandy beaches were selected. Articles with exclusively taxonomic approaches have not been included. The compilation was complemented by searching for references cited within selected articles, and by gathering information from Lattes Platform (the Brazilian researchers' scientific production system). We also sent the list of selected papers to researchers of institutions based along the Brazilian coast for them to complement the data.

To physically characterize Brazilian beaches (objective 1), we used the classification proposed by AB'SÁBER (2003) (see below). Studies about ecosystem goods and services provided by Brazilian beaches (objective 2), as well as researches on the main impacts and threats to this ecosystem (objective 3) are scant; therefore, the discussion of these topics has been based on our personal 
experience and worldwide studies. To determine current knowledge on Brazilian sandy beaches (objective 4), and to discuss their priorities and perspectives (objectives 4-6), the selected studies were classified according to 1) geographic region (N, NE, SE, and $\mathrm{S}), 2$ ) primary focus (population, community, and impact), 3) publication date, and 4) sampling frequency (months to years and number of sampling events during the study) (Annex 1: http://www.io.usp.br/index.php/arquivos/ send/337-vol-64-special-issue-2-2016/3909-annex-933).

\section{RESULTS AND DISCUSSION}

\section{PHYSICAL CHARACTERISTICS OF BRAZILIAN BEACHES}

Beaches are dynamic environments strongly influenced by physical factors such as wave action, tides, and sediment type. Different combinations of these factors determine the morphodynamic characteristics of the beaches and result in a wide variety of types, from reflective beaches (with steep slopes, composed of coarse sand, and having a tidal range of up to $2 \mathrm{~m}$ ) to tidal flats (with gentle slopes, composed of fine grained sand, and usually having a tidal range above $4 \mathrm{~m}$ ) (DEFEO; MCLACHLAN, 2005; MCLACHLAN; BROWN, 2006).

Because of the large latitudinal extent of its coast and the influence of various tidal and climatic patterns, Brazil has a large variety of beaches. Beaches range from just a few meters to more than $200 \mathrm{~km}$ in length, such as Cassino Beach (RS). The morphodynamic characteristics of these beaches are defined by regional climatic and oceanographic conditions, which do not coincide with the regional or political division of Brazil. Thus, a more appropriate categorization of the Brazilian coast by using its geomorphological and phytogeographic characteristics was undertaken by AB'SÁBER (2003), who divided it into six sectors: Equatorial Amazonian Coast, North Northeast, East Northeast, East, Southeast, and South.

The Equatorial Amazonian Coast covers the states of Amapá, Pará, and Maranhão and extends for approximately $1200 \mathrm{~km}$, comprising more than $15 \%$ of the Brazilian coast (ISAAC; BARTHEM, 1995). This area is characterized by low relief and broad coastal plains dominated by semidiurnal macro-tides with a mean range of $4.5 \mathrm{~m}$ (maximum of $7 \mathrm{~m}$ in Maranhão, $6 \mathrm{~m}$ in Pará, and $12 \mathrm{~m}$ in Amapá) (SOUSA et al., 2011). The combination of low relief and macro-tides favors the occurrence of low-water terraces and muddy tidal flats in this region.
The sandy beaches are predominantly intermediate or dissipative (EL-ROBRINI et al., 2006). The Amazon River divides the sector into two segments: the north (Amapá and northwestern Pará), with abundant muddy plains, and the south (northeastern Pará and Maranhão), with sandy and sandy-muddy beaches, mud flats and a predominance of mangrove forests (SZLAFSZTEIN; LARA, 2002). The vast majority of intertidal beaches are wide (between 200 and $500 \mathrm{~m}$ ) and, due to the abundance of rivers flowing down to the coast, salinity is generally low (less than 30) and follows the seasonal variations in rainfall during the rainy season, reaching more than 35 in the dry months and less than 10 in the rainy months (SILVA et al., 2011).

The northeastern coast is the longest among those of all Brazilian regions (approximately $40 \%$ of the entire coast) and has a diverse landscape and relief, with the presence of several types of beaches dominated by semidiurnal meso-tides (ranging between 2 and $4 \mathrm{~m}$ ). As half of this coast faces northwards and half eastwards, it has been divided into the northern sector of the Northeast and the eastern sector of the Northeast.

The northern sector of the Northeast comprises northeastern Maranhão, Piauí, Ceará, and northern Rio Grande do Norte and is characterized by large expanses of beach in front of sandy ridges (sandbanks) and dunes (MATTHEWS-CASCON; LOTUFO, 2006). In its western region, this sector is dominated by intermediate beaches with bars and grooves, while the eastern region is dominated by dissipative beaches and is characterized by a rockier shore with an extensive coastal tableland that borders the ocean with cliffs and paleocliffs. A peculiarity observed in the eastern region of this sector is the meeting of the caatinga (a desert vegetation) with the sea, a phenomenon rare anywhere in the world.

The eastern sector of the Northeast (east of Rio Grande do Norte, Paraíba, Pernambuco, and Alagoas) comprises a strip of sandy coves and shallow shelf edges, dominated by narrow beaches that are partly located between sandstone reefs (AB'SÁBER, 2003), which are often associated with calcareous algae and corals. These sandstone reefs form strands parallel to the coast and can reach several kilometers in length, protecting the coast from high energy coastal dynamics and creating a great diversity of landscapes such as beaches directly exposed to wave action, protected beaches, rocky coasts, areas with prairie marine grasses, and tidal flats with mangrove vegetation. 
The Eastern sector covers the beaches of Sergipe, Bahia, and northern Espírito Santo, and like the northeastern coast, is subject to a climatic regime of semidiurnal meso-tides. This sector presents large continuous stretches of almost rectilinear form, with beaches of fine to very fine sand in front of shelves, arched deltas, and dune fields. During the summer, a dry season when the Disturbed Eastern Currents (Eastern Waves) have a strong influence, the morphodynamic beach states alternate between dissipative and intermediate (with a depositional trend). During the winter, when there is an increased frequency of rainfall, the dissipative state predominates due to the increased wave energy associated with the advance of cold fronts.

The Southeast sector (central south of Espírito Santo, Rio de Janeiro, São Paulo and Paraná) is the most diverse and rugged coastal macro-sector in the country and is influenced by a semidiurnal micro-tidal regime. In general, this sector presents distinct morphological characteristics between its northern and southern regions. The northern region (central south of Espírito Santo to the northern region of São Paulo) has a highly indented coastline, composed of bays and coves, and a dominance of reflective beaches, with coarse particle sizes, high sloping beach faces, and almost no surf zone. The southern section (south of São Paulo and Paraná) is characterized by a rather homogeneous, rectilinear coastline and high energy dissipative beaches with wide intertidal zones, low inclination, a predominance of fine sand, and homogeneous, plane beach profiles (AMARAL; BORZONE, 2008).

The configuration of the South sector (Santa Catarina and Rio Grande do Sul) begins with the end of the forested escarpments of the Serra do Mar on the border between Paraná and Santa Catarina. It is the second most ragged section of the Brazilian coast (especially in its northern portion) and, like the Southeast sector, is subject to a micro-tidal regime. The southern portion of this sector ends in a long, wide rectilinear coastline, dominated by dissipative and intermediate beaches as far as the Uruguayan border. In this southern stretch of the sector, there is prominent spatial variability in the morphodynamic and textural characteristics, with the presence of bimodal sediment beaches composed of fine sand and organic debris (BARROS et al., 1994). Due to the frequent passage of strong cold fronts and cyclones during the winter (KRUSCHE et al., 2002), the beaches of the southern region are strongly influenced by the winds of the quadrant (CALLIARI; KLEIN, 1993; PARISE et al., 2009).
ECOSYSTEM GOODS AND SERVICES PROVIDED BY BRAZILIAN BEACHES

Beaches provide many fundamental ecosystem goods and services such as storage and transport of sediment, shoreline protection, filtration of large volumes of water, and nutrient cycling (SCHLACHER et al., 2008; DEFEO et al., 2009). In addition to these services, Brazilian beaches provide socioeconomic goods and services that are essential for human populations, particularly related to fishing and tourism (PROJETO ORLA, 2002).

Shellfish harvesting in the intertidal region, and fishing with drag nets in the surf zone are one of the main activities carried out by coastal populations and are widespread practices throughout Brazil. As sandy beaches are used for the launching and beaching of small boats, they also have a fundamental role in fishing near the coast. Due to their scenic beauty and the tropical climate characteristic of most of Brazil, the Brazilian beaches represent ideal places for rest and recreation; thus, many coastal cities have a tourism-based economy. Furthermore, some Brazilian beaches provide other goods and services, including the cultivation of seaweed and crustaceans, the exploitation of sea salt (especially in the northeastern region of the country), and the cultivation of molluscs (mainly in Southern Brazil).

Brazilian beaches also play a significant role in biodiversity conservation by providing landing sites, foraging habitats, and nesting grounds for a large number of terrestrial and marine organisms, including several species of birds (VOOREN; CHIARADÍA, 1990; VOOREN, 1998; RODRIGUES, 2000; BARBIERI; HVENEGAARD, 2008; AZEVEDO JÚNIOR; LARRAZABAL, 2011) and five species of turtle: Chelonia mydas (green turtle), Eretmochelys imbricata (hawksbill turtle), Caretta caretta (loggerhead turtle), Lepidochelys olivacea (olive ridley turtle), and Dermochelys coriacea (leatherback turtle) (MARCOVALDI; MARCOVALDI, 1985, 1999).

\section{IMPACTS}

Because sandy beaches are impacted by both terrestrial and marine environments, they are among the most vulnerable ecosystems. In Brazil, the main sources of disturbance to sandy beaches are (1) human interference (road construction, real estate, groins, breakwaters, sea walls, etc.), (2) chemical and organic pollution, and (3) tourism.

Since the early twentieth century, particularly in the Southeast, development and landfills have profoundly 
transformed the coastal landscape. Large expanses of beaches and dunes have been eliminated to allow the construction of buildings, which has compromised the beach ecosystem in many regions. Even today, these transformations are carried out constantly, with large coastal restoration projects, real estate developments, and roads being constructed along the coast, especially on the dunes and backshore. The construction of walls or barriers to protect the coastline is also a frequent human interference along the Brazilian coast. Although these structures are built to protect the region beyond the barrier, they modify the transport of sand within beaches and from beach to beach, which increases the erosion process (MUEHE, 2003; 2006).

Urban, industrial, and port development also have an impact on Brazilian beaches. Due to a lack of regulation or to disrespect for existing legislation, cities and industries dump waste rich in organic and inorganic compounds directly into the sea or rivers that flow into the ocean, thereby altering the physico-chemical characteristics of the water and causing an oxygen deficit in the sediment. Industrial activities on the beaches or in nearby areas, as observed in salt production facilities and shrimp farms in the northeast, also trigger changes in beach biota. Port activities may be associated with the release of waste or antifouling compounds, leakage, dredging of access channels, and introduction of exotic species. As a result, there has been a reduction in faunal diversity and an increase in the dominance of a few tolerant species in areas near beaches surrounded by intense urban development, particularly in industrialized and port areas (OMENA et al., 2012).

Although it is an essential source of income for many cities, tourism is another pressure on Brazilian beaches. The movement of vehicles and intense trampling, especially in the upper littoral and supra-littoral zones, eliminates species and interferes with the breeding and nesting of birds (VELOSO et al., 2008; DEFEO et al., 2009; VIEIRA et al., 2012). Litter left behind by beachgoers - if not taken out to sea, leading to the contamination of islands and oceans - is usually removed by mechanical cleaning. During this process, not only the waste but also the sand and all the fauna and organic matter associated with it are removed, thereby reducing populations and communities, and changing the trophic processes and energy cycling within the ecosystem (BORZONE; ROSA, 2009; DEFEO et al., 2009).

In addition to the impact of human activities on land, beaches are among the most vulnerable marine environments to the impacts of global climate change such as rising sea level, increased frequency and magnitude of extreme events, coastal erosion, rising sea temperatures, and ocean acidification. The Intergovernmental Panel on Climate Change highlights that human interference with the climatic system is already occurring and has resulted in the disturbance of natural systems on all the continents and in all the oceans (IPCC, 2014). Current predictions for the effects of climate change on the Brazilian coast, while heterogeneous, indicate increased air and seasurface temperatures, and rising sea levels throughout national territory (RAICICH, 2008; MARENGO et al., 2010). Although the exact magnitude of the impact of these changes on the beaches is not yet clearly defined, related ecological changes (e.g., changes in phenology, physiology, and distribution of species) are increasingly evident (DEFEO et al., 2009).

The forecasting and modeling performed in several studies indicate that changes in global temperature will result in rising sea levels and an increase in the frequency and intensity of extreme events such as cold fronts associated with extratropical cyclones. These effects may promote erosion of the coastline, flooding by storm surge, changes in tidal amplitude, and changes in sedimentary patterns (CALLIARI; KLEIN, 1993; CALLIARI et al., 1998; MUEHE, 2006). These impacts may result in changes to the biota and morphodynamics of beaches in the short and long term as a result of changes in the composition of the sediment, slope, area available for occupation by the organisms, and, in extreme conditions, the loss of intertidal and backshore areas (SOLA; PAIVA, 2001; GALLUCI \& NETO, 2004; NEGRELLO FILHO, 2005; COCHOA et al., 2006; ALVES; PEZZUTO, 2009; DEFEO et al., 2009). Variations in rainfall distribution may modify the solid discharge (sediment) from rivers and the volume of fresh water that reaches the oceans, also contributing to changes in the morphodynamics of beaches and the salinity of seawater. Ocean acidification will reduce calcification rates and calcium metabolism in marine organisms, including various species of molluscs and crustaceans present on beaches (DEFEO et al., 2009). In addition, an increase in temperature can cause excessive harmful algal blooms, which will influence the quality of the coastal region (TURRA et al., 2013).

As the beaches of southern Brazil are highly influenced by the ENSO phenomenon (El Niño Southern Oscillation El Niño and La Niña), they may be the most affected by global climate change. MUEHE (2003) emphasizes that in Rio Grande do Sul, waves rarely exceed 2 m; however, during the passage of cold fronts, the waterline can reach 
the base of the dunes (approximately $1.7 \mathrm{~m}$ above the mean level) and may significantly increase their erosive potential (CALLIARI et al., 1998). In addition to changes in topographic profiles, extreme events can also cause massive mortality of biota, mainly due to embankments (entrapment of organisms in the swash zone in the upper beach zones) (DEFEO; CARDOSO, 2002; SILVA et al., 2008).

\section{Current knowledge of Brazilian BeACHeS}

A total of 126 published studies on the ecology of the macrofauna of sandy beaches was recorded. These studies were conducted on 172 beaches over a period of approximately forty years, the first of them being published in 1976 (Annex 1: http://www.io.usp.br/ index.php/arquivos/send/337-vol-64-special-issue-22016/3909-annex-933). Studies were recorded on the four Brazilian coastal regions; however, the number of publications relating to each of the regions is quite unbalanced (Annex 1: http://www.io.usp.br/index.php/ arquivos/send/337-vol-64-special-issue-2-2016/3909annex-933, Figure 1). Approximately $84 \%$ of the studies were conducted in the southeastern and southern regions $(n=107)$, while only $2 \%(n=3)$ evaluated beaches in the northern region. This discrepancy can be attributed mainly to the degree of occupation and development of each region. The installation date and number of universities, as well as the resulting presence of experts, are other factors that contribute to such differences between regions in the number of studies conducted.

Investigations were also clustered within each region. Due to logistical conveniences, the studies were mostly conducted on beaches close to universities or research centers. The best example of this concentration is the state of São Paulo, which has the largest number of studies conducted on sandy beaches among the Brazilian states; yet, little or nothing is known about most of its coastline (Figure 1). Almost all studies on the São Paulo coast have focused on northern beaches, an area that has the support of the University of São Paulo (USP). The local concentration of studies, however, is not unique to the São Paulo beaches. In the northeastern region, the studies have focused mainly on certain beaches in Ceará and Pernambuco; in the southeastern region, apart from the north coast of São Paulo, most studies have been performed on beaches located in the city of Rio de Janeiro; while in the southern region, the studies were conducted mainly in the regions of Pontal do Paraná (PR), Babitonga Bay (SC), and Cassino Beach (RS).

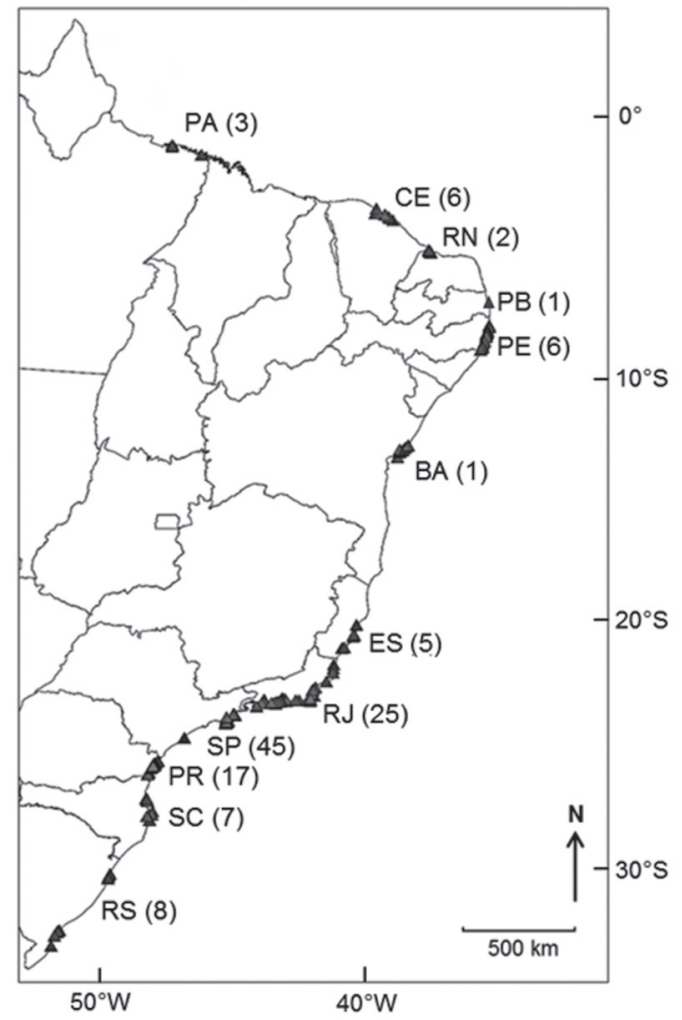

Figure 1. Location map of Brazilian beaches studied in published papers on benthic ecology. Numbers in parentheses correspond to the number of articles conducted in each state.

Although research on the sandy beaches of the Brazilian coast began in the 1970s, it was only in the late 1990 s that the number of studies became more prominent (Figure 2). Almost all the work conducted (96\%) focused on the description of population and community patterns, and linked these to environmental characteristics, particularly sediment type, salinity, and waves.

Most studies (75\%) have had a duration of one year or less. Research with a monthly sampling regime covering 12 months has been the most frequent and has accounted for $50.4 \%$ of the total number of studies analyzed, while $26.4 \%$ of the studies were performed by collecting only one sample per beach. Approximately $17.6 \%$ of the studies have had a duration of up to two years and only seven $(5.6 \%)$ lasted more than two years.

Species with broad geographic distributions, such as the crustaceans Emerita brasiliensis, Excirolana brasiliensis (PAGLIOSA et al., 1998; CARDOSO et al., 2003; VELOSO; CARDOSO, 1999; PETRACCO et al., 2003; CAETANO et al., 2006; EUTRÓPIO et al., 2006), and Ocypode quadrata (TURRA et al., 2005; BLANKENSTEYN，2006; NEVES; BEMVENUTI, 


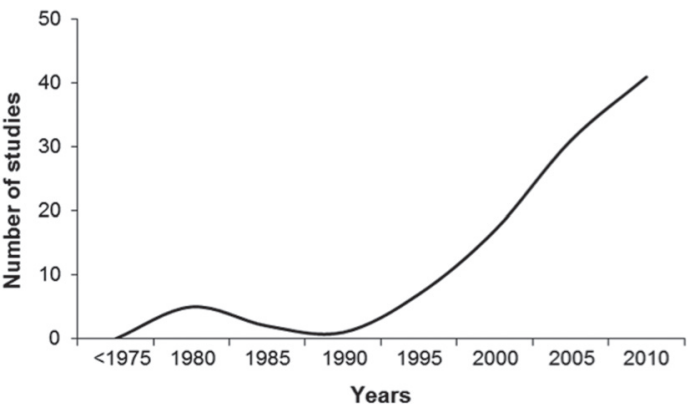

Figure 2. Number of published papers on benthic ecology of Brazilian beaches since 1970 .

2006; ARAUJO et al., 2008; SOUZA et al., 2008; MAGALHÃES et al., 2009; POMBO; TURRA, 2013), the bivalve Anomalocardia brasiliana (ARRUDA-SOARES et al., 1982; NARCHI, 1976; BARREIRA; ARAUJO, 2005; LUZ; BOEHS, 2011; MATTOS; CARDOSO, 2012; RODRIGUES et al., 2013; BELÉM et al., 2013; CORTE et al., 2014, CORTE, 2015; CORTE et al. 2015), and the polychaetes Scolelepis spp (SANTOS, 1991, 1994; SOUZA, BORZONE, 2000; MACCORD, AMARAL, 2007; LEÃO et al., 2012) were the most studied species.

Although the number of studies on Brazilian beaches does not allow adequate evaluation of the existing biodiversity in this environment, some patterns in the spatial distribution of the most frequently studied species can be established (Figure 3). The crustaceans Atlantorchestoidea brasiliensis and Ocypode quadrata and the insects Bledius spp are some of the most common species in the supra-littoral zone of Brazilian beaches, while the bivalves Anomalocardia brasiliana and Donax hanleyanus, the crustacean Emerita brasiliensis, and the polychaetes Capitella spp and Scolelepis spp are often found in the mid-littoral zone. In the infra-littoral zone of many Brazilian beaches, the sand dollar Mellita quinquiesperforata and the bivalve Tellina spp are common.

\section{PRIORITIES AND PERSPECTIVES}

The great heterogeneity of Brazilian beaches and the limited knowledge of their biodiversity highlight the urgent need for further studies to gain a better understanding of this ecosystem. Basic faunal surveys, aimed at biodiversity assessment, are still required in all Brazilian regions, especially in the northern and northeastern regions. In the southeastern and southern regions, a better distribution of studies is necessary to make a better visualization of the local and regional heterogeneity of the beaches possible.

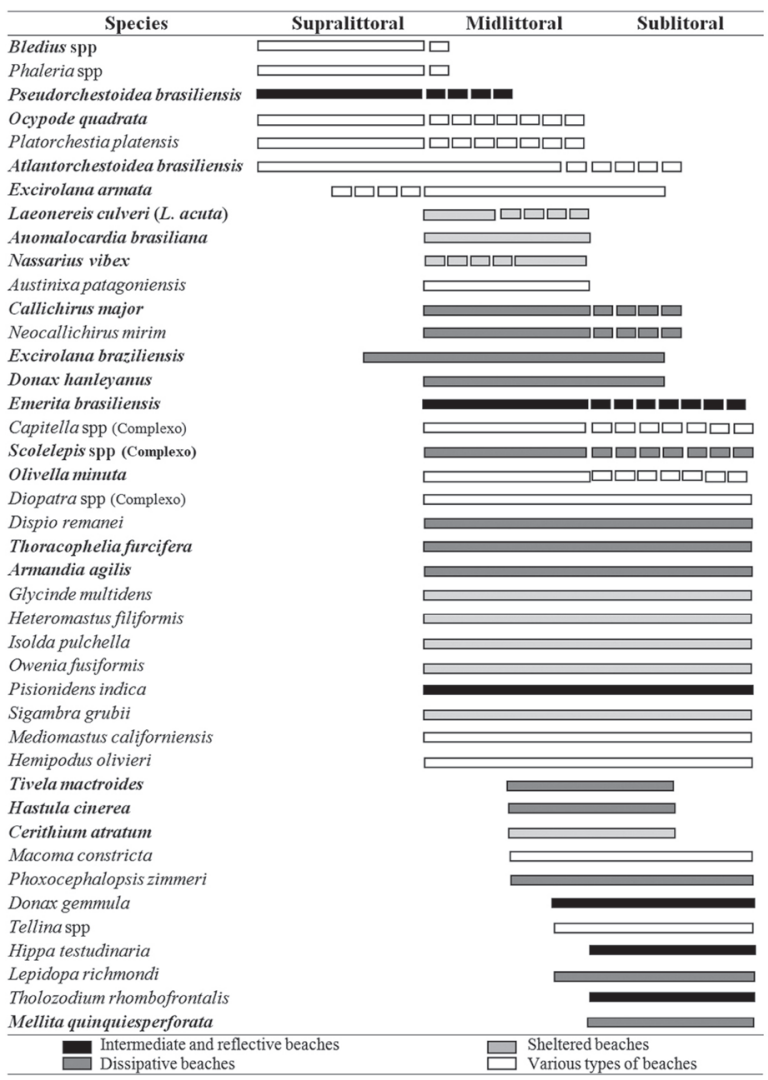

Figure 3. Spatial distribution of dominant species along Brazilian beaches. Names in bold indicate species for which population studies have been conducted.

In addition to studying a broader range of areas, temporal replication of sampling is necessary to allow the compilation of long-term data series. The dominance of studies having a duration of less than one year (many with only one sample collection per area) brings out the sparse temporal replication of studies conducted on Brazilian beaches and highlights the need to work with long-term data series. Several processes related to populations and communities of benthic macrofauna, such as recruitment, zonation, and intra- and inter-specific interactions, may change at intervals of years or decades, and only from long-term monitoring can one achieve a better understanding of active processes on beaches and refine the existing hypotheses (TURRA et al., 2014).

Standardization of the methodologies used and the systematic application of monitoring protocols for large spatial and temporal scales is an essential strategy required to ensure environmental changes such as habitat degradation, reduced primary and secondary productivity, and biological invasions are documented (TURRA et al., 2013). From this homogeneous and long-term approach, 
consistent data will be obtained, which will serve as a baseline for descriptive and predictive modeling of the responses of benthic communities under different scenarios of global and regional changes, in addition to formulating proposals for corrective action. In this context, the ReBentos Beaches Working Group, following methodological and logistical discussions, formulated a number of protocols for the long-term monitoring of some of the most widespread and common species (Polychaeta: Scolelepis; Maxillopoda: Talitridae, Ocypode quadrata; Insecta: Bledius) as well as of macrofaunal communities on Brazilian beaches (http:// www.rebentos.org). These protocols were formulated with readiness, methodological simplicity, and low cost in mind, and they are an important step towards achieving the necessary knowledge to understand and conserve the biodiversity of Brazilian beaches.

In addition to descriptive studies, field and laboratory experiments are necessary to understand differences resulting from anthropogenic impacts and climate change. Mensurative and manipulative experiments have been used to assess the impacts of anthropogenic activities such as vehicle traffic, recreation, construction of breakwaters, and nourishment on the macrofauna of sandy beaches, and their results have contributed significantly to a better understanding of the strength and resilience of this ecosystem (BARROS, 2001; BESSA et al., 2013). Assessments before and after the occurrence of extreme events, with adequate temporal and spatial replication, (see UNDERWOOD; CHAPMAN, 2005 and included references) can provide key information to help understand these phenomena and their consequences.

Studies on the secondary production of key species should be intensified because they are essential to the understanding of processes of energy transfer in the ecosystem of sandy beaches (PETRACCO et al., 2012; 2013). Research on the physiology and gene expression patterns of the species that occur on sandy beaches should also be encouraged. Given that the ability of a species to cope with changes in its environment is related to its complement of genes (SOMERO, 2010), the integration of biological, ecological, and environmental data with biomolecular processes can be an effective tool for the verification of the effects of environmental change on different species, thereby creating a basis for predicting how adaptive evolution can occur in response to global climate change (SOMERO, 2010; LOCKWOOD et al., 2010; LOCKWOOD; SOMERO, 2011).

Improved interactions between scientists and decision makers are also essential for efficient management and conservation strategies to be formulated and applied. Often, conducting medium- and long-term studies is plagued by a lack of resources, which could be more easily obtained if there were a collaborative framework between managers and promoters. On the other hand, the decisions made by managers may be more accurate if they were supported by scientific evidence. More effective collaborations among researchers from different institutions and disciplines is also another key aspect in the training of students with better analytical capabilities (TURRA et al., 2013), as well as seeking to improve the understanding of current researchers. Evaluation of a wide range of physicochemical characteristics and biological components will allow for a comprehensive understanding of sandy beaches and will enable effective measures to be taken in the near future.

\section{Conclusion}

Brazil has a large and diverse number of sandy beaches which play a key role in biodiversity and the support of human populations. Despite their importance, knowledge about these beaches is sparse, and Brazilian historical and socioeconomic characteristics endanger this ecosystem. To gain a better understanding of Brazilian beaches, systematic and long-term studies are required on multiple scales. Experimental and population studies and/or those that incorporate biological, ecological, and environmental data with biomolecular processes should also be encouraged and will add important information to the understanding of Brazilian beaches and their biodiversity. Improved interactions among scientists and decision makers must be pursued as these may facilitate further studies and could lessen the impact of some policy measures. Only on the basis of a better understanding of Brazilian beaches can the real impacts of environmental change be understood and effective measures to conserve this ecosystem be proposed.

\section{ACKNOWLEDGEMENTS}

We would like to thank Thalita Forroni, who contributed to the bibliographic study, and Ana Tereza Lyra Lopes and Emanuelle Fontenele Rabelo, who provided valuable information. Special thanks are due to Dr. Alexander Turra for his support and valuable suggestions. This work was funded by grants Edital MCT/CNPq/MEC/CAPES/ FNDCT; FAPs No 47/2010; SISBIOTA BRASIL; FAPESP: 2010/52323-0; CNPq: 563367/2010-5. We also appreciate the valuable comments of the anonymous reviewer. 


\section{REFERENCES}

AB’SÁBER, A. N. Litoral do Brasil: Brazilian Coast. São Paulo: Motalivros, 2003.

ALVES, E. S.; PEZZUTO, P. R. Effect of cold fronts on the benthic macrofauna of exposed sandy beaches with contrasting morphodynamics. Braz. J. Oceanogr., v. 57, n. 2, p. 73-96, 2009.

AMARAL, A. C. Z.; BORZONE, C. A. Macrofauna bentônica: praias do Sudeste e Sul do Brasil. Bol. Ass. Bras. Biol. Mar., v. 1, n. 3, p. 6-10, 2008.

AMARAL, A. C. Z.; JABLONSKI, S. Conservation of marine and coastal biodiversity in Brazil. Conserv. Biol., v. 19, p. 625-631, 2005 .

ARAÚJO, C. C. V.; ROSA, D. M.; FERNANDES, J. M. Densidade e distribuição espacial do caranguejo Ocypode quadrata (Fabricius, 1787) (Crustacea, Ocypodidae) em três praias arenosas do Espírito Santo, Brasil. Biotemas, v. 21, n. 4, p. 73-80, 2008

ARRUDA-SOARES, H.; SCHAEFFRER-NOVELL, Y.; MANDELLI JR, J. Berbigão Anomalocardia brasiliana (Gmelin, 1791), bivalve comestível da região da Ilha do Cardoso, Estado de São Paulo, Brasil: Aspectos biológicos de interesse para a pesca comercial. Bol. Inst. Pesca, v. 9, p. 2138,1982

AZEVEDO JÚNIOR, S. M.; LARRAZÁBAL, M. E. Conservação de Aves Migratórias Neárticas no Brasil: Salina Diamante Branco. In: VALENTE, R. M.; SILVA, J. M. C.; STRAUBE, F. C.; NASCIMENTO, J. X. L. (Orgs.). Conservação de Aves Migratórias Neárticas no Brasil. Belém: Conservação Internacional, 2011. p. 146-149.

BARBIERI, E.; HVENEGAARD, G. T. Seasonal occurrence and abundance of shorebirds at Atalaia Nova Beach in Sergipe State, Brazil. Waterbirds, v. 31, n. 4, p. 636-644, 2008

BARREIRA, C. A. R.; ARAÚJO, M. L. R. Ciclo reprodutivo de Anomalocardia brasiliana (Gmelin, 1791) (Mollusca, Bivalvia, Veneridae) na praia do Canto da Barra, Fortim, Ceará, Brasil. Bol. Inst. Pesca, v. 31, n. 1, p. 9-20, 2005.

BARROS, F. Ghost crabs as a tool for rapid assessment of human impacts on exposed sandy beaches. Conserv. Biol., v. 97, p. 399-404, 2001

BARROS, F. C. R.; CALLIARI N, L. J.; GIANUCA, N. M. Estudo preliminar da macrofauna da Praia dos Concheiros. Notas Técnicas CECO/UFRGS, v. 7, p. 33-37, 1994.

BELÉM, T. P.; MOURA, R. S. T.; HENRY-SILVA, G. G. Distribuição e densidade do bivalve Anomalocardia brasiliana em praias do Rio Grande do Norte durante um período de pluviosidade atípica. Biotemas, v. 26, n. 1, p. 109-122, 2013.

BESSA, F.; CUNHA, D.; GONÇALVES, S. C.; MARQUES, J. C. Sandy beach macrofaunal assemblages as indicators of anthropogenic impacts on coastal dunes. Ecol. Indic., v. 30, p. 196-204, 2013.

BLANKENSTEYN, A. O uso do caranguejo maria-farinha Ocypode quadrata (Fabricius) (Crustacea, Ocypodidae) como indicador de impactos antropogênicos em praias arenosas da Ilha de Santa Catarina, Santa Catarina, Brasil. Rev. Bras. Zool., v. 23, n. 3 , p. $870-876,2006$.

BORZONE, C. A.; ROSA, L. C. Impact of oil spill and posterior clean-up activities on wrack-living talitrid amphipods on estuarine beaches. Braz. J. Oceanogr., v. 57, n. 4, p. 315-323, 2009.
CAETANO, C. H. S.; CARDoso, R. S.; Veloso, V. G.; SILVA, E. S. Population biology and secondary production of Excirolana braziliensis (Isopoda: Cirolanidae) in two sandy beaches of southeastern Brazil. J. Coast. Res., v. 22, n. 4, p. 825-835, 2006.

CALLIARI, L. J.; KLEIN, A. H. F. Características morfodinâmicas e sedimentológicas das praias oceânicas entre Rio Grande e Chuí, RS. Pesquisas, v. 20, n. 1/2, p. 48-56, 1993.

CALliARI, L. J.; TOZZI, H. A. M.; KLEIN, A. H. F. Beach Morphology and Coastline Erosion Associated with Storm Surges in Southern Brazil - Rio Grande to Chuí, RS. An. Acad. Bras. Ciênc., v. 70, n. 2, p. 231-247, 1998.

CARDOSO, R; VELOSO, V. G.; CAETANO, C. H. Life history of Emerita brasiliensis (Decapoda: Hippidae) on two beaches with different morphodynamic characteristics. J. Coast. Res., v. 35, p. 392-401, 2003.

COCHÔA, A. R.; LORENZI, L.; BORZONE, C. A. A Influência da Passagem de uma Frente Meteorológica na Distribuição da Macrofauna Bentônica Mesolitoral de uma Praia Arenosa Exposta. Tropic. Oceanogr., v. 34, n. 2, p. 59-71, 2006.

CORTE, G. N. Reproductive cycle and parasitism in the clam Anomalocardia brasiliana (Bivalvia: Veneridae). Inver. Reprod. Devel., v. 59, n. 2, p. 66-68, 2015.

CORTE, G. N.; YOKOYAMA, L. Q.; AMARAL, A. C. Z. An attempt to extend the Habitat Harshness Hypothesis to tidalflats: A case study of Anomalocardia brasiliana (Bivalvia: Veneridae) reproductive biology. Estuar. Coast. Shelf Sci., v. 150, p.136-141, 2014.

CORTE, G. N.; YOKOYAMA, L. Q.; COLEMAN, R.A.; AMARAL, A. C. Z. Population dynamics of the harvested clam Anomalocardia brasiliana (Bivalvia: Veneridae) in Cidade Beach, southeast Brazil. J. Mar. Biol. Assoc. U. K., v. 95, n. 6, p. 1183-1191, 2015.

DEFEO, O.; CARDOSO, R. S. Latitudinal patterns in abundance and life-history traits of the mole crab Emerita brasiliensis on South American sandy beaches. Divers. Distrib., v. 10, n. 2, p. 89-98, 2002.

DEFEO, O.; MCLACHLAN, A. Patterns, processes and regulatory mechanisms in sandy beach macrofauna: a multi-scale analysis. Mar. Ecol. Prog. Ser., v. 295, p. 1-20, 2005.

DEFEO, O.; MCLACHLAN, A.; SCHOEMAN, D. S.; SCHLACHER, T. A.; DUGAN, J.; JONES, A.; LASTRA, M.; SCAPINI, F. Threats to sandy beaches ecosystems: a review. Estuar. Coast. Shelf Sci., v. 81, n. 1, p. 1-12, 2009.

EL-ROBRINI, M.; SILVA, M. M. A.; SOUZA FILHO, P. W. M.; EL-ROBRINI, M. H.; SILVA JÚNIOR, O. G.; FRANÇA, C. F. Pará. In: MUEHE, D. Erosão e progradação no litoral brasileiro. Brasília: MMA, 2006. p. 41-86.

EUTRÓPIO, F. J.; SÁ, F. S.; SÁ, H. S. Ecologia populacional de Emerita brasiliensis SCHIMITT, 1935 (Crustacea, Hippidae) de um trecho da praia de Itapoã, Vila Velha, Espírito Santo, Brasil. Nat, On Line, v. 4, n. 2, p. 67-71, 2006.

GALLUCI, F.; NETTO, S. A. Effects of the passage of cold fronts over a coastal site: an ecosystem approach. Mar. Ecol. Prog. Ser., v. 281, p. 79-92, 2004.

KLEIN, Y. L., OSLEEB, J. P.; VIOLA, M. R. Tourism-generated earnings in the coastal zone: a regional analysis. J. Coast. Res., V. 20 , n. 4, p. 1080-1088, 2004.

KRUSCHE, N.; SARAIVA, J. M. B.; REBOITA, M. S. Normas climatológicas provisórias de 1991 a 2000 para Rio Grande, RS. Rio Grande: FURG, 2002. 
INTERGOVERNMENT PANEL ON CLIMATE CHANGE. Summary for policymakers. In: FIELD, C. B.; BARROS, V. R.; DOKKEN, D. J. ; MACH, K. J.; MASTRANDEA, M. D.; BILIR, T. E.; CHATTERJEE, M.; EBI, K. L.; ESTRADA, Y. O.; GENOVA, R. C.; GIRMA, B.; KISSEL, E. S.; LEVY, A. N.; MACCRAKEN, S.; MASTRANDEA, P. R.; WHITE, L. L. (Eds.). Climate Change 2014: Impacts, Adaptation, and Vulnerability. Part A: Global and Sectoral Aspects. Contribution of Working Group II to the Fifth Assessment Report of the Intergovernmental Panel on Climate Change. Cambridge, and New York: Cambridge University Press, 2014. p. 1-32.

ISAAC, V. J.; BARTHEM, R. B. Os recursos pesqueiros da Amazônia brasileira. Bol. Mus. Para. Emílio Goeldi, v. 11, n. 2, p. 295-339, 1995.

LEÃO, L. S. D.; SOARES-GOMES, A.; COSTA, T.; SANTOS, C. G. Population dynamics and reproductive strategy of Scolelepis goodbodyi (Polychaeta: Spionidae) in a subtropical atlantic beach. Zoologia, v. 29, n. 3, p. 195-202, 2012.

LOCKWOOD, B. L.; SOMERO, G. N. Transcriptomic responses to salinity stress in invasive and native blue mussels (genus Mytilus). Mol. Ecol., v. 20, n. 3, p. 517-529. 2011.

LOCKWOOD, B. L.; SANDERS, J. G.; SOMERO, G. N. Transcriptomic responses to heat stress in invasive and native blue mussels (genus Mytilus): molecular correlates of invasive success. J. Exp. Biol., v. 213, n. PT20, p. 3548-3558, 2010.

LUZ, J. R.; BOEHS, G. Reproductive cycle of Anomalocardia brasiliana (Mollusca: Bivalvia: Veneridae) in the estuary of the Cachoeira River, Ilhéus, Bahia. Braz. J. Biol., v. 71, n. 3, p. 679-86, 2011.

MACCORD, F. S.; AMARAL, A. C. Z. The reproductive cycle of Scolelepis goodbodyi (Polychaeta: Spionidae). Mar. Biol., v. 151, n. 3, p. 1009-1020, 2007.

MAGALHÃES, W. F.; LIMA, J. B.; BARROS, F.; DOMINGUEZ, J. M. L. Is Ocypode quadrata (Fabricius, 1787) a useful tool for exposed sandy beaches management in Bahia State (Northeast Brazil)? Braz. J. Oceanogr., v. 57, n. 2, p. 153$155,2009$.

MARCOVALDI, M. A.; MARCOVALDI, G. G. Projeto Tamar: área de desova, Ocorrência e distribuição das espécies, época de reprodução, comportamento de postura e técnicas de conservação das tartarugas marinhas no Brasil. Brasília: Instituto Brasileiro de Desenvolvimento Florestal (IBDF), 1985.

MARCOVALDI, M. A.; MARCOVALDI, G. G. Marine turtles of Brazil: the history and structure of Projeto TAMAR-IBAMA. Biol. Conserv., v. 91, n. 1, p. 35-41, 1999.

MARENGO, J. A.; NOBRE, C. A.; SALAZAR, L. F. Regional Climate Change Scenarios in South America in the Late XXI Century: Projections and Expected Impacts. Nova Acta Leopold., v. 112, p. 1-15, 2010.

MATTHEWS-CASCON, H.; LOTUFO, T. M. C. Biota Marinha da Costa Oeste do Ceará. Brasília: Ministério do Meio Ambiente (MMA), 2006.

MATTOS, G.; CARDOSO R. S. Population dynamics of two suspension-feeding bivalves on a sheltered beach in southeastern Brazil. Helgol. Mar. Res., v. 66, n. 3, p. 393400, 2012.

MCLACHLAN, A.; BROWN, A. Sandy beaches as ecosystems. Amsterdam: Elsevier Science Publishers, 2006. 373 p.
MUEHE, D. Beach Morphodinamic Research in Brazil: evolution and Applicability. J. Coast. Res., v. SI, n. 35, p. 32-42, 2003.

MUEHE, D. Erosão e progradação no litoral brasileiro. Brasília: Ministério do Meio Ambiente (MMA), 2006.

NARCHI, W. Ciclo anual da gametogênese de Anomalocardia brasiliana (Gmelin, 1791) (Mollusca, Bivalvia). Bol. Zool., v. 1, p. 331-350, 1976.

NEGRELLO FILHO, O. A. A influência do vento sul sobre a estabilidade de associações bênticas da Baía de Paranaguá (Paraná, Brasil). 2005. 101 p. Tese Doutorado (em Zoologia Setor de Ciências Biológicas) - Universidade Federal do Paraná, Curitiba, 2005. http://dspace.c3sl.ufpr.br/dspace/ bitstream/handle/1884/2317/Tese\%20Orlei\%20A.\%20 Negrello\%20Filho.pdf?sequence $=1 \&$ isAllowed $=\mathrm{y}$

NEVES, F. M.; BEMVENUTI, C. E. The ghost crab Ocypode quadrata (Fabricius, 1787) as a potential indicator of anthropic impact along the Rio Grande do Sul coast, Brazil. Biol. Conserv., v. 133, n. 4, p. 431-435, 2006.

OMENA, E. P.; LAVRADO, H. P.; PARANHOS, R.; SILVA, T. A. Spatial distribution of intertidal sandy beach polychaeta along an estuarine and morphodynamic gradient in an eutrophic tropical bay. Mar. Pollut. Bull., v. 64, n. 9, p. 18611873, 2012.

PAGLIOSA, P. R.; FONSECA, A. L.; BORZONE, C. A.; LORENZI, L.; SILVA, G. B.; GUIMARÃES, C. C. R. P.; PEREIRA JR., L.; HOFSTAETTER, M.; GODEFROID, R. S.; OLIVEIRA, E.; CHRISTO, S. W.; UEJIMA, A. M.; QUADROS, J.; FERNANDEZ, D. R. Distribuição de Excirolana braziliensis e E. armata (Isopoda: Cirolanidae) em três praias do litoral paranaense. Atlântica, v. 20, p. 2334, 1998 .

PARISE, C. K.; CALLIARI, L. J.; KRUSCHE, N. Extreme storm surges in the south of Brazil: atmospheric conditions and shore erosion. J. Coast. Res., v. 57, n. 3, p.175-188, 2009.

PETRACCO, M.; VELOSO, V. G.; CARDOSO, R. Population dynamics and secondary production of Emerita brasiliensis (Crustacea: Hippidae) at Prainha Beach, Brazil. Mar. Ecol., v. 24, n. 3, p. 231-245, 2003.

PETRACCO, M.; CARDOSO, R. S.; CORBISIER, T. N; TURRA, A. Brazilian sandy beach macrofauna production: a review. Braz. J. Oceanogr., v. 60, n. 4, p. 473-484, 2012.

PETRACCO, M.; CARDOSO, R. S.; TURRA, A. Patterns of sandy-beach macrofauna production. J. Mar. Biol. Ass. U. K., v. 93, n. 7, p. 1717-1725, 2013.

POMBO, M.; TURRA, A. Issues to Be Considered in Counting Burrows as a Measure of Atlantic Ghost Crab Populations, an Important Bioindicator of Sandy Beaches. PLoS ONE, v. 8, n. 12 , p. e83792, 2013.

PROJETO ORLA: fundamentos para gestão integrada. Brasília: Ministério do Meio Ambiente, 2002.

RAICICH, F. A review of sea level observations and low frequency sea level variability in South Atlantic. Phys. Chem. Earth., v. 33, n. 3, p. 239-249. 2008.

RODRIGUES, A. A. F. Seasonal abundance of neartic shorebirds in the gulf of Maranhão, Brazil. J. Field. Ornithol., v. 71, n. 4, p. 665-675, 2000

RODRIGUES, A. M. L.; BORGES-AZEVEDO, C. M.; COSTA, R. S.; HENRY-SILVA, G. G. Population structure of the bivalve Anomalocardia brasiliana, (Gmelin, 1791) in the semi-arid estuarine region of northeastern Brazil. Braz. J. Biol., v. 73, n. 4, p. 819-833, 2013. 
SANTOS, P. J. P. Morphodynamical influence of a temporary freshwater stream on the population dynamics of Scolelepis gauch (Polychaeta: Spionidae) on a sandy beach in Southern Brazil. Bull. Mar. Sci., v. 48, n. 3, p. 657-664, 1991.

SANTOS, P. J. P. Population dynamics and production of Scolelepis gaucha (Polychaeta: Spionidae) on the sandy beaches of Southern Brazil. Mar. Ecol. Prog. Ser., v. 110, p. 159-165, 1994.

SCHERER, M. Beach Management in Brazil: Topics for Consideration. J. Int. Coast. Zone Manag., v.13, n. 1, p 3-13. 2013.

SCHLACHER, T. A.; DUGAN, J.; SCHOEMAN, D. S.; LASTRA, M.; JONES A.; SCAPINI, F.; MCLACHLAN, A.; DEFEO, O. Sandy beaches at the brink. Divers. Distrib., v. 13, n. 5, p. 556-560, 2007.

SCHLACHER, T. A.; SCHOEMAN, D. S.; DUGAN, J.; LASTRA, M.; JONES, A.; SCAPINI, F.; MCLACHLAN, A. Sandy beach ecosystems: key features, management challenges, climate change impacts, and sampling issues. Mar. Ecol., v. 29, n. 1, p. 70-90, 2008.

SILVA, P. S. R.; NEVES, L. P.; BEMVENUTI, C. E. Temporal variation of sandy beach macrofauna in cassino beach, extreme south Brazil. Braz. J. Oceanogr., v. 56, n. 4, p. 257270. 2008 .

SILVA, N. I. S.; PEREIRA, L. C. C.; GORAYEB, A., VILACONCEJO, A.; SOUSA, R. C.; ASP, N. E.; COSTA, R. M. Natural and social conditions of Princesa, a macrotidal sandy beach on the Amazon Coast of Brazil. J. Coast. Res., v. SI 64, p. 1979-1983, 2011.

SOLA, M. C. R.; PAIVA, P. C. Variação Temporal da Macrofauna Bentônica Sublitoral da praia da Urca (RJ) após a Ocorrência de Ressacas Braz. J. Oceanogr., v. 49, n. 1, p. 137-142, 2001

SOMERO, G. N. The physiology of climate change: how potentials for acclimatization and genetic adaptation will determine 'winners' and 'losers'. J. Exp. Biol., v. 213, n. 6, p. $912-920,2010$.

SOUSA, R. C.; PEREIRA, L. C. C.; SILVA, N. I. S.; OLIVEIRA, S. M. O.; PINTO, K. S. T.; COSTA, R. M. Recreational carrying capacity of Amazon macrotidal beaches during the peak vacation season. J. Coast. Res., v. SI 64, p. 1292-1296, 2011.

SOUZA, J. R. B.; LAVOIE, N.; BONIFÁCIO, P. H.; ROCHA, C. M. C. Distribution of Ocypode quadrata (Fabricius, 1787) on sandy beaches of northeastern Brazil. Atlântica, v. 30, n. 2, p. 139-145, 2008.

SOUZA, J. R. B.; BORZONE, C. A. Population dynamics and secondary production of Scolelepis squamata (Polychaeta: Spionidae) in an exposed sandy beach, Southern Brazil. Bull. Mar. Sci., v. 67, n. 1, p. 221-233, 2000.
SZLAFSZTEIN, C.; LARA, R. Sea level rise and coastal land use in North Brazil: legal aspects. International Symposium on Lowlying Coastal Areas: Hydrology and Integrated Coastal Zone Management. Bremerhaven: Germany, 2002. p. 353360.

TURRA, A.; GONÇALVES, M. A. O.; DENADAI, M. R. Spatial distribution of the ghost crab Ocypode quadrata in lowenergy tide-dominated sandy beaches. J. Nat. Hist., v. 39, n. 23, p. 2163-2177, 2005.

TURRA, A.; CRÓQUER, A.; CARRANZA, A.; MANSILLA, A.; ARECES, A. J.; WERLINGER, C.; MARTÍNEZBAYÓN, C.; NASSAR, C. A. G.; PLASTINO, E.; SCHWINDT, E.; SCARABINO, F.; CHOW, F.; FIGUEROA, F. L.; BERCHEZ, F.; HALL-SPENCER, J. M.; SOTO, L. A.; BUCKERIDGE, M. S.; COPERTINO, M.; SZÉCHY, M. T. M.; GHILARDI-LOPES, N. P.; HORTA, P.; COUTINHO, R.; FRASCHETTINI, S.; LEÃO, Z. M. A. N. Global environmental changes: setting priorities for Latin American coastal habitats. Glob. Change Biol., v. 19, n. 7, p. 1965-1969, 2013.

TURRA, A., PETRACCO, M.; AMARAL, A. C. Z., DENADAI, M. R. Temporal variation in life-history traits of the clam Tivela mactroides (Bivalvia: Veneridae): Density-dependent processes in sandy beaches. Estuar. Coast. Shelf Sci., v. 150, p. 136-141, 2014.

UNDERWOOD, A. J.; CHAPMAN, M. G. Design and Analysis in Benthic Surveys. In: ELEFTHERIUOU, A.; McINTYRE, E. (Eds.). Methods for the study of marine benthos. Oxford: Wiley-Blackwell Science, 2005. p. 1-42.

VELOSO, V. G.; NEVES, G.; LOZANO, M.; PEREZHURTADO, A.; GAGO, C. G.; HORTAS, F.; GARCIA, F. Responses of talitrid amphipods to a gradient of recreational pressure caused by beach urbanization. Mar. Ecol., v. 29, n. 1, p. 126-133, 2008.

VELOSO, V. G.; CARDOSO, R. Population biology of the mole crab Emerita brasiliensis (decapoda: hippidae) at Forte São Joao Beach, Brazil. J. Crust. Biol., v. 19, n. 1, p. 147-153, 1999.

VIEIRA, J. V.; BORZONE, C. A.; LORENZI, L.; CARVALHO, F. G. Human impact on the benthic macrofauna of two beach environments with different morphodynamic characteristics in southern Brazil. Braz. J. Oceanogr., v. 60, n. 2, p. 137-150, 2012.

VOOREN, C. M. Aves marinhas e costeiras. In: SEELIGE, U.; ODEBRECHT, C.; CASTELLO, J. P. (Eds.). Os Ecossistemas costeiro e marinho do extremo sul do Brasil. Rio Grande: Ecoscientia, 1998. p. 170-176.

VOOREN, C. M.; CHIARADIA, A. Seasonal abundance and behaviour of coastal birds on Cassino beach, Brazil. Ornitol. Neotrop., v. 1, p. 9-24, 1990. 
